Судук 0. Ю. [1; ORCID ID: 0000-0002-4620-4389], к.с.-Г.н., доцент кафедри менеджменту

${ }^{1}$ Національний університет водного господарства та природокористування, м. Рівне

\title{
ОСОБЛИВОСТІ БІЗНЕС-ПЛАНУВАННЯ ТА ЕКСПЕРТИЗИ ПРОЄКТІВ В АГРАРНІЙ СФЕРІ УКРАЇНИ
}

У статті обгрунтовано необхідність розроблення технології бізнеспланування проєктів в аграрній сфері. Аргументацією наведеного обгрунтування $\epsilon$ аналіз переваг $\mathrm{i}$ недоліків існуючих технологій бізнеспланування. Досліджено сутність бізнес-плану та обгрунтовано необхідність планування виробничо-господарської діяльності сільськогосподарських підприємств. Визначено місце та роль бізнеспланування у системі загального стратегічного розвитку підприємства, як важливої умови функціонування, економічного розвитку та зростання сільськогосподарських підприємств в непередбачуваних ринкових умовах. Розглянуто основні задачі, які вирішує система бізнеспланування та особливості складання бізнес-плану на підприємствах сільського господарства. Запропоновано пріоритетні напрямки та заходи бізнес-планування для забезпечення зростання, розвитку та вдосконалення діяльності підприємств в аграрній сфері.

Ключові слова: бізнес-планування; аграрний сектор; ризик; показники ефективності; проєкт; ЮНІДО; методологія; експертиза.

Постановка проблеми. Глибокі соціально-економічні перетворення в агропромисловому комплексі України, перехід до ринкових відносин об'єктивно вимагають застосування нових методів ведення господарської діяльності, використання сучасних методів управління, в тому числі бізнес-планування. У сучасних умовах бізнес-планування $€$ надійним інструментом підвищення прибутковості та рентабельності підприємства.

Проєкти в аграрній сфері порівняно 3 іншими проєктами характеризуються підвищеним рівнем ризиковості. Причинами високого рівня ризиків $є$ те, що аналітики підприємств не здатні прогнозувати кліматичні умови, які впливають на врожайність сільськогосподарських культур, як наслідок, на дохідність діяльності сільськогосподарського підприємства. 3 огляду на це умовою започаткування і реалізації таких проектів $€$ обґрунтування їхньої окупності й прибутковості у визначений період часу. Таке обґрунтування, як правило, наводиться в бізнес-планах. Більшість 
технологій бізнес-планування має універсальний характер. Вони не враховують специфіки окремих видів інвестиційних проектів в аграрній сфері, зокрема інноваційних проектів та проектів, що направлені на формування доданої вартості. Проблема бізнеспланування інноваційних проєктів полягає в тому, що досі відсутні спеціально розроблені технології бізнес-планування, які б дозволяли адекватно аргументувати економічну ефективність вкладення коштів в аграрну сферу з урахуванням тих чинників, які відрізняють проекти в аграрній сфері від усіх інших інвестиційних проектів.

Аналіз останніх досліджень і публікацій. Аналіз діючих стандартів бізнес-планування $[1 ; 2 ; 3 ; 4 ; 5]$, науково-методичних праць [6; 7; 8], а також інших джерел [9; 10; 11] дозволяє стверджувати, що для реалізації проєктів в аграрному секторі відсутні спеціальні технології бізнес-планування. Як наслідок, стандартні технології адаптуються до конкретних умов ініціаторами проєктів на основі власного досвіду та переконань. Це здебільшого $€$ причиною суб'єктивізму бізнес-планування проєктів у сфері аграрного виробництва.

Метою статті $€$ аналіз переваг та недоліків існуючих технологій бізнес-планування на предмет їхньої прийнятності щодо ефективності вкладання коштів в аграрну сферу.

\section{Виклад основного матеріалу дослідження}

Бізнес-планування у сільському господарстві забезпечує формування цілей та засобів їх досягнення за певний період діяльності підприємства; об'єднує всі елементи виробництва в цілісну виробничо-господарську систему й забезпечує їі необхідний, передбачуваний розвиток, узгоджує потенційні можливості підприємства з потребами товарного ринку. Основним його змістом $€$ підвищення продуктивності й ефективності роботи підприємства.

Бізнес-план сільськогосподарського підприємства - це документ, що передбачає систему доказів про вигідність проєкту, а також уміщує визначений ступінь життєздатності підприємства, передбачає ризики підприємницької діяльності й перспективний погляд на підприємство та його ринкове середовище.

Бізнес-план $є$ комплексним документом, який відображає всі основні аспекти підприємницького проекту й $€$ однією з функцій управління. Встановлено, що під час складання бізнес-плану необхідно враховувати особливості, які притаманні лише сільськогосподарському виробництву: сезонність, різну тривалість робочого циклу, витрачання частини своєї продукції на поновлення процесу виробництва, неоднакову потребу в оборотних коштах 
протягом року, обмеження, які поширюються на підприємства галузі в системі земельних відносин.

Технології бізнес-планування відрізняються рівнем деталізації і переліком показників, які використовуються для обґрунтування економічних вигод від реалізації бізнесових ідей. Аналіз технологій бізнес-планування на виробничих підприємствах показав, що більшість із них базується на стандартах ЮНІДО, ЄБРР, KPMG, BFM Group, а також Master Plans, TACIS тощо.

Ураховуючи те, що ЄБРР був створений для сприяння промисловому й торговельному розвитку країн Центральної Європи та Центральної Азії, то практично всі проекти, які ним реалізовуються, мають міжнародний характер, вони передбачають залучення іноземних інвестицій і кредитів. Очевидно, що майнові і цивільні відносини, які виникають між учасниками реалізовуваних проектів під патронатом ЄБРР, супроводжуються економічними, політичними, правовими та іншими ризиками.

До поширених технологій бізнес-планування належить також технологія, що базується на стандарті KPMG. Компанія KPMG надає аудиторські та консультаційні послуги з податкових та фінансових питань клієнтам, серед яких найбільші українські та міжнародні компанії, а також низка неурядових організацій та фінансових інститутів. Технологія бізнес-планування, розроблена компанією KPMG, стала стандартом, оскільки KPMG запропонувала на ринок програмний продукт «Інтерактивна бізнес-модель підприємства», який $є$ електронним документом у форматі MS Excel. Цей продукт уможливлює при формуванні бізнес-плану в будь-якому форматі розробляти інтерактивну бізнес-модель підприємства, яка $\epsilon$ інструментом фінансового аналізу й джерелом отримання необхідних фінансових показників [2; 8].

Технологія бізнес-планування за стандартом KPMG близька до технології бізнес-планування за стандартом ЮНІДО. $Є$ лише певні відмінності в наповненні кожного 3 етапів технології бізнеспланування. Попри це перевагою бізнес-плану, підготовленого за стандартом KPMG, $€$ те, що в ньому значна увага приділяється обчисленню проектної собівартості продукції (послуг), що засвідчує прозорість використовуваного підходу до управління витратами й дозволяє на передпроєктній стадії реалізації бізнесової ідеї аналізувати можливі резерви зниження собівартості. Щодо недоліків цієї технології, то в ній надто закритими $є$ інформація щодо особливостей матеріально-технічного забезпечення виконання виробничої програми підприємства та порядок забезпечення проєкту виробничими потужностями. 
Однією 3 альтернатив під час розробки бізнес-планів $\epsilon$ використання стандарту Master Plans. Компанія Master Plans Experts $\epsilon$ всесвітньовідомою організацією, яка надає послуги з бізнеспланування. I хоча при рекламуванні своїх послуг компанія акцентує увагу на тому, що запропоновані нею бізнес-плани враховують усі індивідуальні особливості клієнтів, слід визнати, що технологія їхньої розробки досить високо формалізована для кредитних, інвестицій, екологічних та інших проєктів. Причинами цього є, з одного боку, набутий компанією досвід у бізнес-плануванні, типологізації бізнесових ідей, а з іншого боку - те, що компанія Master Plans Experts так само, як і компанія KPMG, взяла за основу при бізнесплануванні технологію ЮНІДО.

Логічність етапів цієї технології важко поставити під сумнів. Бізнес-план, побудований за стандартом MasterPlans, добре структурований. Користувач такого бізнес-плану послідовно, на основі дедуктивного методу, отримує аргументи про економічну доцільність і реалістичність реалізації бізнесової ідеї.

Альтернативою цій технології $€$ технологія бізнес-планування відповідно до стандарту BFM Group. BFM Group Inc. - об'єднання кількох компаній, які спеціалізуються на розробленні креативних стратегій розвитку бізнесу і дослідження ринку. За участі BFM Group Inc. реалізовано сотні успішних інвестиційних проектів у всьому світі. Набутий досвід і широка мережа представництв перетворили використовувану компанією технологію бізнес-планування на один із найпоширеніших стандартів. Порівняно з технологіями бізнеспанування на засадах застосування стандартів ЮНІДО, ЄБРР, КРМG, MasterPlans ця технологія найбільш деталізована. У ній окремо приділяється увага започаткуванню підприємством зовнішньоекономічної діяльності, що $€$ важливим для проєктів, реалізація яких виходить за межі національних ринків, зокрема, 3 точки зору врахування витрат на придбання ліцензій, необхідність сплати ввізних мит, попередження можливих правових конфліктів із зарубіжними партнерами тощо. Характерною особливістю цієї технології $\epsilon$ також те, що майже половина етапів іiі реалізації присвячена фінансовому плануванню та обгрунтуванню прибутковості проєкту. Ця технологія прийнятна для бізнеспланування проєктів сільськогосподарських підприємств.

Для проєктів в сфері аграрного виробництва найбільш прийнятною $\epsilon$ технологія бізнес-планування, яка базується на стандарті TACIS [5]. Незважаючи на певну простоту цієї технології порівняно 3 вищенаведеними, доцільно визнати, що вона орієнтована саме на виконання сільськогосподарських проєктів. Так, 
перший етап технології присвячений розкриттю передісторії необхідності реалізації таких проектів. На другому етапі акцентується увага на продукті. Третій етап дає уявлення про потенційні ринки й очікуваний рівень попиту на продукт. Аргументування обраної моделі управління проєктом реалізації бізнесової ідеї відбувається на четвертому етапі. Завершується технологія бізнес-планування обґрунтуванням обсягу необхідних інвестицій та фінансовим плануванням, зокрема, обсягу доходів, витрат, активів, пасивів тощо. Недоліком цієї технології $€$ те, що в ній не відображено виробничої програми підприємства, а також плану матеріально-технічного забезпечення іiі виконання. Як наслідок, непрозорою $є$ інформація про виробничі потужності, необхідні для реалізації проєкту, графік їхнього впровадження й експлуатації. Крім того, технологія бізнес-планування відповідно до стандарту TACIS не конкретизує, яка частка проєкту фінансуватиметься за рахунок власних коштів підприємства, а яка за рахунок кредитів.

Висновки і перспективи подальших досліджень. Таким чином, окрім стандартних позицій, які відображаються в бізнес-планах усіх інвестиційних проектів, у бізнес-планах реалізації проєктів в аграрній сфері необхідно відображати стійкість ведення бізнесу на внутрішньому ринку та можливість експорту сільськогосподарської продукції; рівень ризикованості проєкту; варіативність окупності вкладених у проєкт коштів за умови використання монопольного й конкурентного ціноутворення; рівень диверсифікованості джерел фінансування проєкту, зокрема диверсифікованості банківського кредитування; рівень державної підтримки цього напрямку діяльності. Незважаючи на те що окремі технології бізнеспланування для реалізації проєктів в аграрній сфері мають певні переваги порівняно з іншими, спільними їхніми недоліками є: неможливість точного прогнозу витрат і доходів від реалізації проєкту, оскільки існує значна залежність від кліматичних умов; відсутні адекватні механізми фінансування проєктів в аграрній сфері, а також розподілу прибутків або збитків від їх реалізації. На підставі врахування цих недоліків подальші дослідження необхідно проводити у напрямку розроблення такої технології бізнеспланування проектів, яка б забезпечувала поінформованість потенційних реалізаторів проекту про ймовірність прибутковості проекту, безпечність його виконання, адаптивність до змін ринкової кон'юнктури.

1. Стандарты бизнес-планов ЮНИДО. URL: www.probp.ru/publish/standard1.php (дата звернення: 10.11.2020). 2. Структура бизнес-плана по стандартам EБPP. URL: 
Серія «Економічні науки»

Випуск 4(92) 2020 p.

http://pro-consulting.com.ua (дата звернення: 10.11.2020). 3. The European Bank for Reconstruction and Development : website. URL: http://www.ebrd.com (дата звернення: 10.11.2020). 4. KPMG : website. URL: http://www.kpmg.com (дата звернення: 10.11.2020). 5.TACIS. Как разработать бизнес-план. URL: http://www.inventica.ru (дата звернення: 15.11.2020). 6. Макаренко С. М. Бізнес планування : навчально-методичний посіб. Херсон : СТАР ЛТД. 2017. 224 с. 7. Масловська М. В., Перевозчикова Н. О. Особливості процесу бізнес-планування в сучасних умовах розвитку України. Ефективна економіка. 2013. № 11. С. 1-3. 8. Кваша О. С., Фоміна В. В. Бізнес-планування у діяльності організації: європейські стандарти, основні методологічні підходи та базові процедури. Економіка $i$ суспільство. С. 268-275.

URL:

http://www.economyandsociety.in.ua/journal/12_ukr/45.pdf (дата звернення: 03.12.2020). 9. Михайленко О.В., Лобас А.А. Характеристика особливостей складання бізнес-планів. Вчені записки ТНУ імені В.І. Вернадського. Сер. Економіка $і$ управління. 2018. № 3. Т. 29 (68). С. 74-77. 10. Интерактивная бизнес-модель предприятия. URL: http://progressive-management.com.ua (дата звернення: 03.12.2020). 11. Оформлення і стиль бізнес-плану. URL: http://buklib.net (дата звернення: 11.12.2020).

\section{REFERENCES:}

1. Standartyi biznes-planov YUNIDO. URL: www.probp.ru/publish/standard1.php (data zvernennya: 10.11.2020). 2. Struktura byznes-plana po standartam EBRR. URL: http://pro-consulting.com.ua (data zvernennia: 10.11.2020). 3. The European Bank for Reconstruction and Development : website. URL: http://www.ebrd.com (data zvernennia: 10.11.2020). 4. KPMG : website. URL: http://www.kpmg.com (data zvernennia: 10.11.2020). 5. TACIS. Kak razrabotat biznes-plan. URL: http://www.inventica.ru (data zvernennia: 15.11.2020). 6. Makarenko S. M. Biznes planuvannia : navchalno-metodychnyi posib. Kherson : STAR LTD. 2017. 224 s. 7. Maslovska M. V., Perevozchykova N. O. Osoblyvosti protsesu biznes-planuvannia v suchasnykh umovakh rozvytku Ukrainy. Efektyvna ekonomika. 2013. № 11. S. 1-3. 8. Kvasha O. S., Fomina V. V. Biznes-planuvannia u diialnosti orhanizatsii: yevropeiski standarty, osnovni metodolohichni pidkhody ta bazovi protsedury. Ekonomika i suspilstvo. $\quad$ S. $268-275$.

URL: http://www.economyandsociety.in.ua/journal/12_ukr/45.pdf (data zvernennia: 03.12.2020). 9. Mykhailenko 0. V., Lobas A. A. Kharakterystyka osoblyvostei skladannia biznes-planiv. Vcheni zapysky TNU imeni V.I. Vernadskoho. Ser. Ekonomika i upravlinnia. 2018. № 3. T. 29 (68). S. 74-77. 10. Interaktivnaya biznes-model predpriyatiya. URL: http://progressive-management.com.ua (data zvernennia: 03.12.2020). 11. Oformlennia i styl biznes-planu. URL: http://buklib.net (data zvernennia: 11.12.2020). 


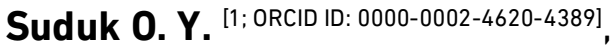
Candidate of Agricultural Sciences (Ph.D.), Associate Professor

${ }^{1}$ National University of Water and Environmental Engineering, Rivne

\section{FEATURES OF BUSINESS PLANNING AND EXAMINATION OF PROJECTS IN THE AGRICULTURAL SPHERE OF UKRAINE}

The article substantiates the necessity of developing the technology of innovative projects' business planning. Advantages and disadvantages of existing business planning technologies have been grounded.

The article deals with the essence of the business plan as a multifunctional and universal planning document, which has a wide range of applications in the activities of economic entities management. It considers the need of developing the business plans and its functions.

The article investigates the nature of the business plan and the necessity of planning production and business activities of agricultural enterprises. The place and role of business planning in the general strategic development of the company as an important condition for the functioning the economic development and growth of agricultural enterprises in unpredictable market conditions. Consider the main problem that solves the system of business planning and features a business plan for agricultural enterprises. Main structural sections of the business plan, their functional orientation and ways of its implementation have been indicated. Priority ways and measures of business planning for growth, development and improvement of agricultural enterprises have been proposed.

The article investigates that in a market economy one of the main factors of competitiveness and efficiency of an organization is the welldesigned business plan that allows you to effectively develop business activities, attract investors, partners and credit resources; used to improve an enterprise's management and forecasting activities. In modern business conditions, the investment business plan is a working tool used in all areas of business.

Keywords: business planning; agricultural sector; risk; efficiency indicators; project; UNIDO; methodology; expertise. 
Судук Е. Ю. [1; ORCID ID: 0000-0002-4620-4389], к.с.-Х.н., доцент кафедры менеджмента

${ }^{1}$ Национальный университет водного хозяйства и природопользования, г. Ровно

\section{ОСОБЕННОСТИ БИЗНЕС-ПЛАНИРОВАНИЯ И ЭКСПЕРТИЗЫ ПРОЕКТОВ В АГРАРНОЙ СФЕРЕ УКРАИНЫ}

В статье обоснована необходимость разработки технологии бизнеспланирования проектов в аграрной сфере. Аргументацией приведенного обоснования является анализ преимуществ и недостатков существующих технологий бизнес-планирования. Исследована сущность бизнес-плана и обоснована необходимость планирования производственнохозяйственной деятельности сельскохозяйственных предприятий. Определено место и роль бизнес-планирования в системе общего стратегического развития предприятия, как важного условия функционирования, экономического развития и роста сельскохозяйственных предприятий в непредсказуемых рыночных условиях. Рассмотрены основные задачи, которые решает система бизнес-планирования и особенности составления бизнес-плана на предприятиях сельского хозяйства. Предложено приоритетные направления и мероприятия бизнес-планирования для обеспечения роста, развития и совершенствования деятельности предприятий в аграрной сфере.

Ключевые слова: бизнес-планирование; аграрный сектор; риск; показатели эффективности; проект; ЮНИДО; методология; экспертиза. 